\title{
How Do Initil Public Offerings Perform In Kenya? An Analysis of Offer and Closing Prices
}

\author{
By Francis Mambo Gatumo \\ United States International University P.O BOX 1466-080
}

\begin{abstract}
Private companies raise permanent capital by means of initial public offering. This study investigated the performance of IPOs listed between 2000 and 2014 in Nairobi Securities Exchange. The purpose of the investigation was to establish the average raw total return (RTR) and the market adjusted abnormal return $(M A A R)$ in the short run in order to determine whether raw total return and the market adjusted abnormal return outperform the Nairobi Securities Exchange (20) index. The independent variables were the closing price on the first day of trading and the offer price. The dependent variables were the raw total return and the market adjusted abnormal return, while the Nairobi Securities Exchange (20) Index was the moderating variable. An investigation of initial public offerings enhance a company's planning to source of capital for growth. Data was sourced from IPO prospectuses and the daily price listing by Nairobi Securities Exchange. The population of the study comprised of twenty-one firms listed within the study period. Literature review focused on the performance of IPOs in the short run as well as the comparison between raw total return and Nairobi Securities Exchange (20) index. The design of the study was explanatory. Explanations were made through descriptive and inferential statistics. The Values ( $p$-values $=0.073>0.05$ level of significance) reveal that there was no statistically significant difference between RTR and NSE (20) index. The study concluded that in the short run, Initial Public Offerings do not outperfm the market. The findings of the study were significant in informing both the issuers and the investors when to make gains and reduce investment losses.
\end{abstract}

Key words: Finance, financing, initial public offering, seasoned equity offering, private placing offering and underwriters, underpricing, raw total return, market adjusted abnormal return.

\section{Introduction}

Initial Public Offering (IPO) is a method of raising permanent equity capital by private companies. An IPO is, therefore, a stage in a company's life cycle. Consequently, the status of such a company changes from private status to public status. To raise funds, a private company issue equity instruments to be sold to the public at an offer price (PC). Equity instruments, so issued are the ordinary shares.However, on the first day of trading, the closing price is likely to be equal to the offer price, greater than or lower than the offer price. When the closing price is greater than or lower than the offer price, a financial anomaly occurs. Such financialanomaly is called IPO underpricing or IPO overpricing. Such phenomenon is a case of IPO mispricing. IPO mispricing is calculated by use of the raw total return.Heerden and Alagidede(2012) sated that underpricing was calculated as the percentage difference between the closing price on the first day of trading and the offer price. Furthermore, to establish whether raw total returnoutperform the market index, market adjusted abnormal return (MAAR) is a-applied. MAAR is the percentage fraction between the raw total return and the market index.(Abraham (2015) nalysed 128 IPO firms listd in Malaysi between 2009 and 2014 and found market adjusted abnormal retrun of $20.25 \%$. Thye findings of the study denmonstrate the existence of underpricing in the Singapore stock market.

An IPO is an important avenue to raise funds, besides raising the profile of the issuing firm. The funds raised are significant in enabling the issuing company to finance its growth activities. The issuing firm, also, acquire publicity. Pagano, Panetta and Zingales (1998) opinioned that firms go public to overcome borrowing constraints by obtaining permanent equity, gain investor recognition and provide the opportunity to the founders exit. Furthermore, Brealey, Myers, and Allen ( 2011)alluded that an IPO results in tradability of company shares through price discovery. Extant literature support the argument that IPOs are underpriced, in the short run,(Loughran \& Ritter, 1995),(Rock, Why New Issues are Underpriced, 1986), (Ritter \& Welch, 2002),(Abraham, 2015), (Soyemi, Olabisi, \&Oluwalajiki (2015),Heerden and Alagidede (2012). In kenya, Wabwire, Owour, Onyuma and Njuguna ( 2013) posit that lack of IPO relevant information hinder investors from knowing the actual performance of their investments.Moreover,Kipngetich, Kibet, Guyo, and Kipkoskey(2011)found underpricing of $49.44 \%$. In the same market, Marangu and Makori ( 2013) stated that KenGen Ltd shares were undepriced by $236 \%$ while, Cheluget, Letting, and Mohat ( 2016) found average underpricing of $40.28 \%$. These differences in the level of IPO underpricicing motivated this research.The objectives of this research were twofold: first the determination of the magnitude of raw total return and secondly,to ascertain the extent of outperformance against the Nairobi Securties Exchange (20) Index. The rest of the study address literature review, research methodology, results and findings,including conclusions and recommendations. 


\section{Literature Review}

Abraham ( 2015) analysed 128 IPO firms listed between 2009 and 2014 in Singapore and applying market adjusted abnormal return found average return of $20.25 \%$. In Italy, DellAcqua, Etro, Teti, and Murri ( 2014) confirm the presence of underpricing based on an analysis of 129 IPO firms listed between 2001 and 2012.They confirm that $2 / 3$ of the reviewed sample underpriced by $6.75 \%$. Baker and Uzaki (2012) analysed 476 IPO firms listed in Malaysia between 2000 and 2011. They found underpricing by $35.87 \%$. Rock(1986) stated that firms price shares at a discount to ensure that uninformed investors bind for IPO shares. Reber and Fong (2006) analyzed 100 IPO firms listed in Singapore between 1998 and 2000. They found that subscription rate had the grearest impact on IPO underpricing.Welch (1989) stated that IPO firms underprice to signal value. Rock ( 1986) stated that uninformed investors are subject to Winner's curse. Therefore IPO firms are complelled to underprice the IPO to compensate uninformed investors.

In South Africa, Heerden and Alagidede( 2012) examined 138 IPO firms listed between 2006 and 2010 and found average market adjusted return of $108.33 \%$ for the first day of trading. In Zimbabwe, DZimiri and Radikoko (2015) analysed 19 IPO firms listed in Zimbabwe Stock Exchange between 1993 and 2003 and confirm average underpricing of $45.4 \%$ and market adjusted abnormal return of 38.4\%.In Tunisia, Zouari, Boudriga, and Boulila ( 2011) examined 34 IPO firms listed in Tunisia between 1992 and 2008. They confirm that the market adjusted abnormal return(MAAR) for three days was 17.8\%. In Ghana, Esumanba, Kpanie, and Benard (2015) analysed 35 IPO firms listed between 1990 and 2009. They found underpricing level of $8.43 \%$. Based on the findings on the African Continent, this study seeks to find whether IPOs in kenya are underpriced or not.

\section{Methodology}

Chorruk and Worthington (2009 ) statethatthere are three methods of computing IPO underpricing: first,they used headline underpricing. Secondly, they applied the underpricing issuer loss and finally the underpricing loss by market value. This study favour the headline underpricing because it is an all-purpose computation that does not focus on a particular equity market actor. In this study, raw total return was calculated using the headline underpricing. The calculated raw total returns was compared with the NSE (20) market Index. The closing price and the offer price were measured in ratio scales and were presented in Kenya shillings, being unit of currency measurement in the country. The raw total return and the market adjusted abnormal returns were measured in percentages, being measures of performance. The closing price and the offer price are observable in the market; while the raw total return and the market adjusted, abnormal returns are computed. Equally too, Nairobi securities Exchange (20) Index is also computed.

All IPO firms listed between 2000 and 2014 were included in the study, except three IPO firms that were dropped from the study due to lack of data. These were Scan Group ltd, Kirwitu Ventures ltd and Centum Investments ltd.

Raw Total Return (RTR) for each IPO $=\frac{P C}{P O}-1$

Average raw return is computed as follows:

Average $\mathrm{RTR}=1 / \mathrm{n} \sum \mathrm{RTRi}$

Return of the market is computed as follows:

$\mathrm{Rm}=\frac{N S E(20) t 1}{N S E(20) t o}-1$

The market-adjusted abnormal return (MAAR) was be computed as follows:

MAAR $=\left(\frac{1+R T R t}{1+R M t}-1\right) * 100$

In Singapore, Abraham (2015) applied MAAR in determining the extent of underpricing of IPOs.

$\overline{M A A R}=1 / n \sum$ MAARit

Based on the hypothesis that $\overline{M A A R}=0$

To test the hypothesis that $M A A R=0$,

t-MAAR will be calculated as follows:

$t-M A A R=\operatorname{MAAR} /(\sigma / \mathrm{N} n)$

The hypothesis is tested at 0.05 level of significance.

\section{Data And Results}

This section presents the raw total return and market adjusted abnormal return(MAAR) for each IPO and an average for all IPOs that were issued between 2000 and 2014 in Kenya.

(a) Descriptive Statistics 
Table 1: Descriptive Statistics for RTR

\begin{tabular}{|l|l|l|l|l|}
\hline Descriptive Statistics & P0 & PC & RTR & \\
\hline N & 18 & 18 & 18 & \\
\hline Mean & 17.24 & 34.08 & 0.49 & \\
\hline Std. Deviation & 17.92 & 73.46 & 1.01 & \\
\hline Minimum & 5.00 & 5.25 & -0.25 & \\
\hline Maximum & 70.00 & 324.00 & 3.63 & \\
\hline Range & 65.00 & 318.75 & 3.88 & \\
\hline Skewness & 2.498 & 0.536 & 2.32 & \\
\hline Kurtosis & 5.46 & 1.038 & 1.04 & \\
\hline
\end{tabular}

Source: Researcher, 2017

Table 1 shows that the Average RTR was $49 \%$.and the standard deviation was 1.01 . The range was 3.88 while the skweness was 2.32 .

Table 2: Descriptive Statistics for MAAR

The values are in percentages except $\mathrm{N}$, skewness and kurtosis

\begin{tabular}{|l|l|}
\hline Variable & MAAR \\
\hline $\mathrm{N}$ & 18 \\
\hline Range & 680.96 \\
\hline Minimum & -46.04 \\
\hline Maximum & 634.92 \\
\hline Mean & 68.06 \\
\hline Std. Deviation & 151.27 \\
\hline Skewness & 3.40 \\
\hline Kurtosis & 13.00 \\
\hline
\end{tabular}

Source: Researcher, 2017

Table 2 shows that the mean of MAAR $=68.06 \%$, while the standard deviation of MAAR was 151.27. The skewness and the range were 3.40 and 680.96 , respectively.

(d)Test statistics of skewness

t-skewness $=\frac{\text { skewness of } M A A R}{\sqrt{\bar{\sigma}} / \boldsymbol{n}}$

The following results were obtained.

$\mathrm{t}$-Skewness $=3.40 /(\sqrt{ } 151.27 / 18)=1.18$

At 0.05 level of significance, the tabulated value based on 17 degrees of freedom was

$\mathrm{t}= \pm 2.110$. Therefore, the skewness of MAAR is not statistically significant to deter the application of inferential nalaysis on MAAR.

Test Statistic for MAAR

The test statistic values were computed as follows:

$\mathrm{t}-$ Statistic $=\frac{\overline{M A A R}}{\sigma M A A R / \sqrt{n}}$

Inferential statistics

Table 3: Test Statistic for MAAR

\begin{tabular}{|c|c|c|c|c|c|}
\hline \multicolumn{6}{|c|}{ Test Value MAAR $=0$} \\
\hline \multirow[t]{2}{*}{$\mathrm{t}$} & \multirow[t]{2}{*}{$\mathrm{df}$} & \multirow[t]{2}{*}{ Sig. (2-tailed) } & \multirow{2}{*}{ Mean Difference } & \multicolumn{2}{|c|}{$95 \%$ Confidence Interval of the Difference } \\
\hline & & & & Lower & Upper \\
\hline 1.909 & 17 & .073 & 68.06222 & -7.1649 & 143.2893 \\
\hline
\end{tabular}

Source: Researcher, 2017

Table 3 shows t-MAAR $=1.909$ and the $\mathrm{P}$ - value $=0.073>0.05$ level of significance. The lower and the upper confidence interval levels consist of zero. Thus, hypothesis 1 , was not rejected.

\section{Conclusion}

The study found that the RTR for firms listed between 2000 and 2014 was $49 \%$. Furthermore, the market adjusted abnormal return (MAAR) was $68.06 \%$, but does not outperform the Nairobi Securities Exchange (20) Index as evidenced by p-values $=0.073>0.05$ level of significance. Based on the research findings, investors in Kenya make substantial capital gains whi8le IPO firms end up with large capital loss. The study recommends that investors should invest in IPOs in Kenya.

\section{Reference}

[1]. Abraham, N. R. (2015). Underpriicng of Initial Public Offering (IPO): Singapore IPO Market 2009-2014. Journal of Management Science and Technology, 3(1).

[2]. Baker, N. B., \& Uzaki, K. (2012). A Test of Initial Public Offering (IPO) underpricing performance in Malaysian Stock Exchange. The Asian Business and Management Conference 2012. Osakla: The International Acadenmic Forum. 
[3]. Brealey, R., Myers, S., \& Allen, F. (2011). Peinciples of Corporate Finance. McGraw-Hill/Irwin Series.

[4]. Cheluget, J., LETTING, N., \& mOHAT, e. (2016). iNVESTORS dEMAND FOR ipOS AND FIRST DAY PERFORMANCE. NAIROBI: 1AMBERT.

[5]. Chorruk, J., \& Worthington, A. C. (n.d.).

[6]. DellAcqua, A., Etro, L., Teti, E., \& Murri, M. (2014). IPO underpricing and Aftermarket performance in Italy. International Journal of Finance and Banking, 1(5).

[7]. DZimiri, M. T., \& Radikoko, I. R. (2015). IPO underpricing and short run performance : An empirical Analysis of its impact to the number of IPO listing on the Zimbabwe Styock Exchnage (ZSE). Journal of Research in Business and Management, 3(11).

[8]. Esumanba, S. V., Kpanie, A. F., \& Benard, b. (2015). Firm specific determinanats of underpricing on the Ghana Stock Exchnage. INternational Reviews of management and Business Research, 4(1).

[9]. Heerden, G. V., \& Alagidede, P. (2012). Short run underpricing of Initial Public offering (IPO) in the Johannesburg Stock Exchnage(JSE). Review of Development Finance, 2.

[10]. Kaaria, M. F., \& makori, M. (2013). An analysis of a succesful initial public offering(IPO) among Nairobi Security Exchnage listed companies. International Journal of Social Sciences and Entrepreneurship, 1(7).

[11]. Kipngetich, T. J., KIbet, B. J., Guyo, S. A., \& Kipkoskey, B. J. (2011). determinats of Initial Public Offer pricing in kenya. Annual Conference on innovation in Business Managment. London: The Centre for Innovations in Business and Management Practice.

[12]. Loughran, T., \& Ritter, J. R. (1995). The New issues Puzzle. The Journal of Finance, 50(1).

[13]. Omran, M. (2005). Underpricing and long run performance of share issue privatizations in the Egyptian Stock Market. The Journal of Financial Research, 28(2).

[14]. Pagano, M., panetta, F., \& Zingales, L. (1998). Why do comapnies go public? An Empirical Analysis. The Journal of Finance, $53(1)$.

[15]. Reber, B., \& Fong, C. (2006). Explaining mispricing of Initial Public Offerings in Singapore. Applied Financial Economics, 16.

[16]. Ritter, J. R., \& Welch, I. (2002). A Review of IPO Activity, pricing and Allocations. The Journal of Finance, 57(4).

[17]. Rock, K. (1986). Why new issues are underpriced. Journal of Financnial Economics, 15.

[18]. Rock, K. (1986). Why New Issues are Underpriced. Journal of Financial Economics, 15.

[19]. Soyemi, K. A., Olabisi, J., \& Oluwalajiki, O. F. (2015). Underpricing of initial Public Offering(IPOs)- Evidence from the Nigerain Stock Exchnage (NSE). Fountain Journal of Management and Social Sciences, 4(2).

[20]. Wabwire, J. M., Owour, G., Onyuma, S., \& Njuguna, A. (2013). The Effects of Initial Public Offer announcement on market returns of listed stocks at the Naoirobi stock Exchnage. International Journal of Research in Management, 3(2).

[21]. Welch, I. (1989). Seasoned Offerings, imitations costs , and the underpricing of Initial Public Offerings. The JOurnal of Finance, 44(2).

[22]. Zouari, S. B., Boudriga, A., \& Boulila, N. T. (2011). Determinnats of IPO underpricing: Evidence from Tunisia. International Journal of Business and Finance Research, 5(1)

APPENDIX 1: COMPANIES LISTED IN NSE (2000 - 2014)

\begin{tabular}{|c|c|c|c|c|}
\hline & COMPANY & & YEAR OF LISTING & $\begin{array}{l}\text { NO. FIRMS LISTED } \\
\text { IN EACH YEAR }\end{array}$ \\
\hline 1 & MUMIAS SUGAR LTD. & RECOVERY & 2001 & 1 \\
\hline 2 & WPP SCAN GROUP LTD. & RECOVERY & 2006 & \\
\hline 3 & KENGEN LTD. & RECOVERY & 2006 & \\
\hline 4 & EAST AFRICA. CABLES & RECOVERY & 2006 & \\
\hline 5 & EVEREADY LTD. & RECOVERY & 2006 & 4 \\
\hline 6 & ACCESS KENYA LTD. & BOOM & 2007 & \\
\hline 7 & KENYA RE. LTD. & BOOM & 2007 & 2 \\
\hline 8 & SAFARICOM LTD. & BOOM & 2008 & \\
\hline 9 & EQUITY BANK LTD. & BOOM & 2008 & \\
\hline 10 & COOPERATIVE BANK LTD. & BOOM & 2008 & 3 \\
\hline 11 & CFC (INSURANCE) LTD. & BOOM & 2010 & 1 \\
\hline 12 & TRANSCENTURY LTD. & RECESSION & 2011 & \\
\hline 13 & BRIT. LTD. & RECESSIONJ & 2011 & \\
\hline 14 & UAP INSURANCE & RECESSION & 2011 & 3 \\
\hline 15 & LONGHORN LTD. & RECESSION & 2012 & \\
\hline 16 & CIC LTD & RECESSION & 2012 & 2 \\
\hline 17 & HOME AFRICA LTD. & RECESSION & 2013 & 1 \\
\hline 18 & $\begin{array}{l}\text { NAIROBI SECURITIES } \\
\text { LTD }\end{array}$ & RECESSION & 2014 & \\
\hline 19 & KURWITU VENTURES & RECESSION & 2014 & \\
\hline 20 & FLAME TREE GROUP LTD. & RECESSION & 2014 & \\
\hline \multirow[t]{2}{*}{21} & ATLAS DEVELOPMENT LTD. & RECESSION & 2014 & 4 \\
\hline & & & & 21 \\
\hline
\end{tabular}

Source: Researcher, 2017 